\title{
Prevalence of tick-borne haemoparasitic infections in Zebu cattle slaughtered in Yenagoa, Bayelsa State
}

\author{
LeBari Barine Gboeloh $1{ }^{*}$ and Akugbebebibo Dominic Araka ${ }^{2}$ \\ ${ }^{1}$ Parasitology Unit, Department of Biology, Ignatius Ajuru University of Education, Port Harcourt, Rivers State, Nigeria. \\ 2 Department of Biology, Bayelsa Medical University, Yenagoa, Bayelsa State, Nigeria.
}

International Journal of Biological and Pharmaceutical Sciences Archive, 2022, 03(01), 024-030

Publication history: Received on 20 December 2021; revised on 29 January 2022; accepted on 30 January 2022

Article DOI: https://doi.org/10.53771/ijbpsa.2022.3.1.0023

\begin{abstract}
The prevalence of tick-borne haemoparasitic diseases in Zebu Cattle (Bos taurus indicus) ready for slaughter in Yenagoa metropolis, Bayelsa State were investigated. Blood samples were collected from the jugular vein of 200 presumably healthy Zebu cattle using $10 \mathrm{ml}$ hypodermal syringe into well- labelled Ethylene Diamine Tetra acetic (EDTA) bottles. Thin and thick blood films were prepared for microscopy. Haematological parameters were determined using the micro haematocrit method. Out of the 200 Zebu cattle examined, 125 (62.5\%) were infected. More female75 (75\%) were infected than male 50 (50\%). The parasites identified were Anaplasma marginale (57.5\%), Bebasia bovis (35.8\%) and Theileria parva (6.7\%). There was a significant reduction ( $\mathrm{P}>0.05)$ in the level of PCV $(20.53 \pm 0.70), \mathrm{Hb}(8.60 \pm 0.30)$

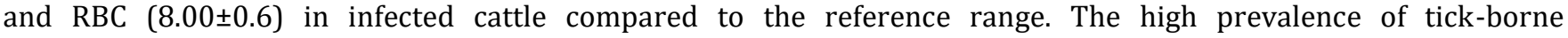
haemoparasites in zebu cattle in the study area could be reduced through proper animal management practice, health orientation of herders, good sanitary habit and proper treatment of infected cattle.
\end{abstract}

Keywords: Haemoparasites; Zebu Cattle; Prevalence; Haematological parameters

\section{Introduction}

Livestock management is highly practiced worldwide on extensive, intensive or semi-intensive basis. The raring of animals have high economic value and has employed approximately 1.3 billion people globally $[1,2,3,4,5]$. The common animals reared in Nigeria are diverse species of ruminants (Cattle, sheep and goats) [5,6]. Among the ruminants, Cattle are regarded as the main source of protein for most households globally. Apart from the supply of protein, products such as milk, hoof, bones, blood, hides and skin from these animals are of great economic benefit to the country and the world at large [6]. The viability and productivity of these animals are affected by tick-borne haemo-parasites such as Anaplasma spp., Babesia spp., Theileria spp. These parasites poise serious health risk to livestock and humans as some are zoonotic. Therefore, their presence is of huge public health threat to humans and livestock productivity [7].

Countries in sub Saharan Africa including Nigeria are mostly affected by these parasites because of the prevailing environmental and socioeconomic conditions that favours the striving of the parasites [8]. In Nigeria, the prevalence of haemoparasites have been reported with variable results $[9,10,11]$. The pathological impact of the diseases caused by these parasites results in reduction in food conversion rates, reduced milk production rates, high fever, weight loss, in coordination, anaemia, abortion and even death of the animals $[7,12]$.

Certain control measures including spraying cattle with chemicals, destruction of vector breeding sites and introduction of natural enemies to feed on vectors (biological control) have been employed in areas where the diseases are reported. Although several studies have been done in Nigeria on the prevalence of haemoparasites in cattle, no such study has

\footnotetext{
* Corresponding author: LeBari Barine Gboeloh

Parasitology Unit, Department of Biology, Ignatius Ajuru University of Education, Port Harcourt, Rivers State, Nigeria. 
been done in Yenegoa, Bayelsa State. This study is there aimed at the study of the prevalence of tick- borne haemoparasitic diseases (TBHDs) and associated haematological changes that occurs in Zebu cattle (Bos taurus indicus) ready for slaughter in Yenagoa metropolis, Bayelsa State, South- South Nigeria.

\section{Material and methods}

\subsection{Study area}

The study was conducted in Yenegoa, Bayelsa State using four abattoirs: Akenfa abattoir ( $\left.4.9212^{0} \mathrm{~N}, 6.2748^{0} \mathrm{E}\right)$, Bayelsa Palm abattoir ( $\left.4.8567^{0} \mathrm{~N}, 6.3436^{\circ} \mathrm{E}\right)$, Swali abattoir $\left(4.9186^{0} \mathrm{~N}, 6.2628^{\circ} \mathrm{E}\right)$ and Tombia abattoir $\left(4.9975^{\circ} \mathrm{N}, 6.2628^{0} \mathrm{E}\right)$ located in Yenagoa metropolis, Bayelsa State. Yenegoa metropolis (Fig. 1) lies between longitude 6015'51E and latitude 4055 ' $29 \mathrm{~N}$ with an estimated geographical area of $706 \mathrm{~km}^{2}$. The metropolis has a population of 352,285 [13]. The climate of the area is the equatorial type or tropical rainforest climate that lies $10^{0}$ to $15^{0}$ latitude of the equator with an annual rainfall of over $2500 \mathrm{~mm}$ per annum with a double maxima of rainfall between June/ July and September/ October with a conventional type of rain (heavy rainfalls accompanied with thunder storms). The climate is noted for hot, humid and wet seasons. The temperature of Yenagoa is approximately about $27^{\circ} \mathrm{C}$. The long period of wet or rainy season between 6-8 months of rains and 3-4-month dry season annually, favours growth of herbs which consequently promotes cattle rearing in the state. This study was conducted within February, 2021 and August, 2021.

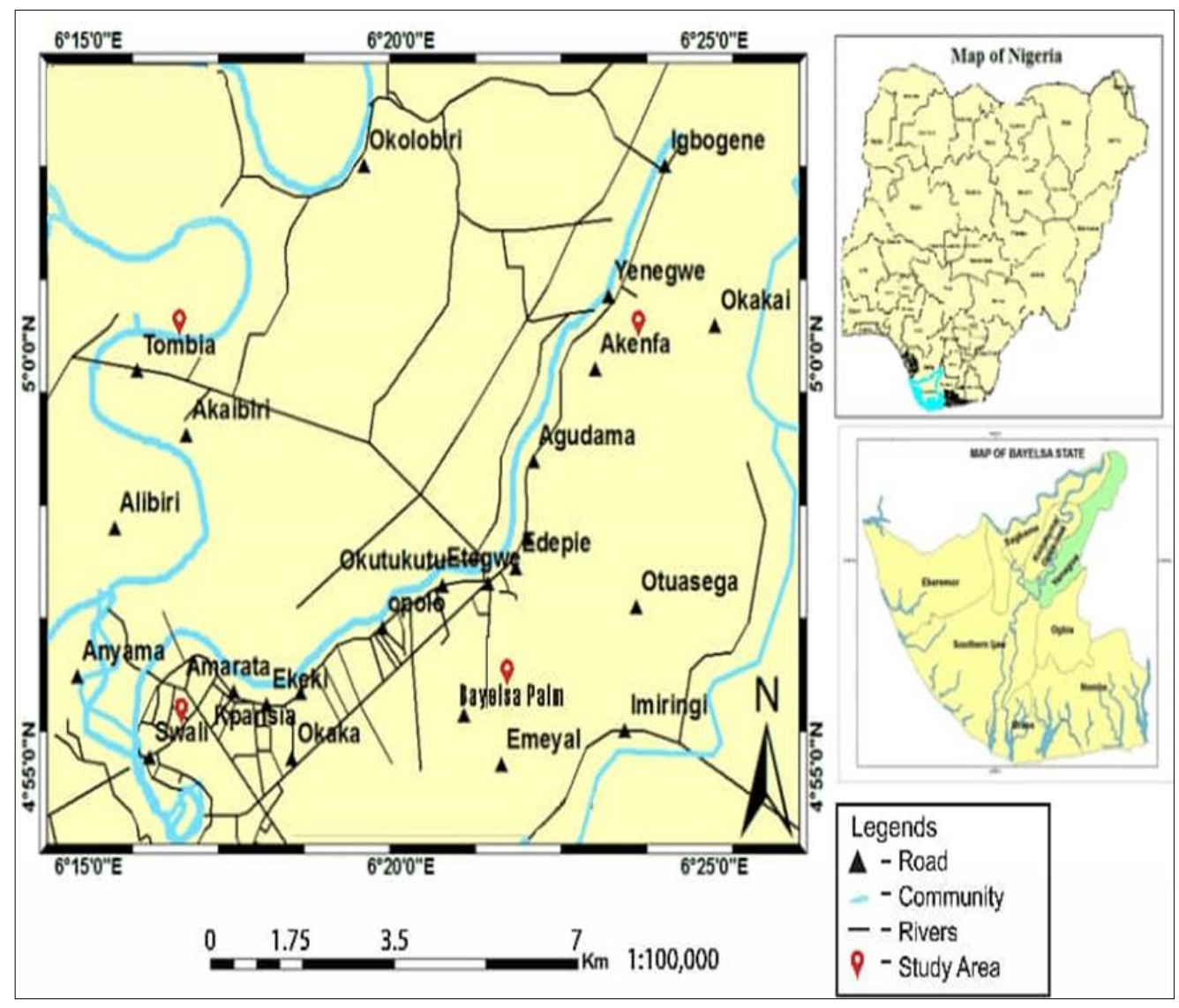

Figure 1 The study area showing the abattoirs

\subsection{Ethical clearance}

Ethical clearance and approval for this study was obtained from the Veterinary Department of the Bayelsa State Ministry of Agriculture Yenagoa, Nigeria. The executives of National Union of Butchers, Bayelsa State also gave the permission for the study.

\subsection{Sample collection}

A total of 200 Zebu cattle (100 males and 100 females) were randomly collected from the four selected abattoirs, 50 cattle that are ready to be slaughtered were randomly sampled from each abattoir. Fresh blood samples were collected 
from these randomly selected $50 \mathrm{Zebu}$, and with the help of the veterinary doctors, $6 \mathrm{ml}$ of blood samples was collected from each cattle using a $10 \mathrm{ml}$ disposable hypodermic syringe, into well labelled Ethylene Diamine Tetra Acetic Acid (EDTA) bottles. The samples were transported in ice packs at $4^{\circ} \mathrm{C}$ to Wiz-Link research laboratory, Yenegoa for parasitological and haematological examinations.

\subsection{Laboratory examination}

Thin and thick blood smears were prepared using the method of [14]. The thin slides were stained with Giemsa the slides were examined under the microscope using X10, X40 and X100 objective lens. The method of [15] was used to identify the haemoparasites were identified using morphological characteristics according to the Atlas of haemoparasites.

\subsection{Determination of haematological parameters}

Pack cell volume (PCV) was determined using microhaematocrit centrifugation technique (MHCT) as described by [16]. While haemoglobin $(\mathrm{Hb})$ concentration was determined using the methods of [17]. The total White Blood Cell (WBC) was determined using the Neubauer haemocytometer. This was derived by diluting the blood in $1 \mathrm{in} 20 \mathrm{ml}$ acid reagent to haemolyse the red blood cells leaving the white blood cells to be counted using the improved Neubauer chamber (haemocytometer) and the number of WBC per litre of blood is calculated as;

$$
\text { WBC count }(\text { per litre })=\text { cells counted } \times 20^{*} \times 10^{6} / 4^{t} \times 0.1^{1}
$$

Where;

$$
*=1 \text { in } 20 \text { dilution of blood, }
$$

$\mathrm{t}=4 \mathrm{~mm} 2$ area counted,

$\mathrm{l}=0.1 \mathrm{~mm}$ depth of the chamber.

The red blood cell (RBC) count was determined by diluting $10 \mathrm{ml}$ of whole blood with $20 \mathrm{ml}$ of saline in a plastic container and allowed to stand for 15 minutes. The mixture was fixed into and counting chamber and observed under the microscope. Mean Corpuscular Volume (MCV) was derived with a calculation as follows:

$$
\mathrm{PCV} \times 10 / \mathrm{RBC}(\mathrm{l} / \mathrm{c}) .
$$

Mean Corpuscular Haemoglobin (MCH) was derived with a calculation as follows;

$\mathrm{HB} \times 10 / \mathrm{RBC}(\mathrm{g} / \mathrm{c})$ while the Mean Corpuscular Haemoglobin Concentration (MCHC) was determined using the following formula.

$$
\mathrm{MCHC}=\mathrm{HB} \times 10 / \mathrm{PCV}(\mathrm{g} / \mathrm{l}) .
$$

\subsection{Data analysis}

Data generated were analysed using statistical package for social science (SPSS version 22) at 0.05 level of significance. Haematological parameters were analysed using ANOVA.

\section{Results}

\subsection{Prevalence of tick-borne haemoparasites}

A total of 200 Zebu cattle (Bos taurus indicus) was examined for the presence of tick-borne haemoparasites out of which $125(62.5 \%)$ were infected with at least one tick-borne haemoparasite. Out of the125 (62.5\%) infected cattle 34 (17\%), 32 (16\%), 30 (15\%) and 29 (14.5\%) were observed in Akenfa, Bayelsa palm, Swali and Tombia abattoirs respectively (Fig. 2). Although cattle from Akenfa had the numerically high rate of infection, there was no significance difference $(\mathrm{P}>0.05)$ in the infection rate among the abattoirs. 


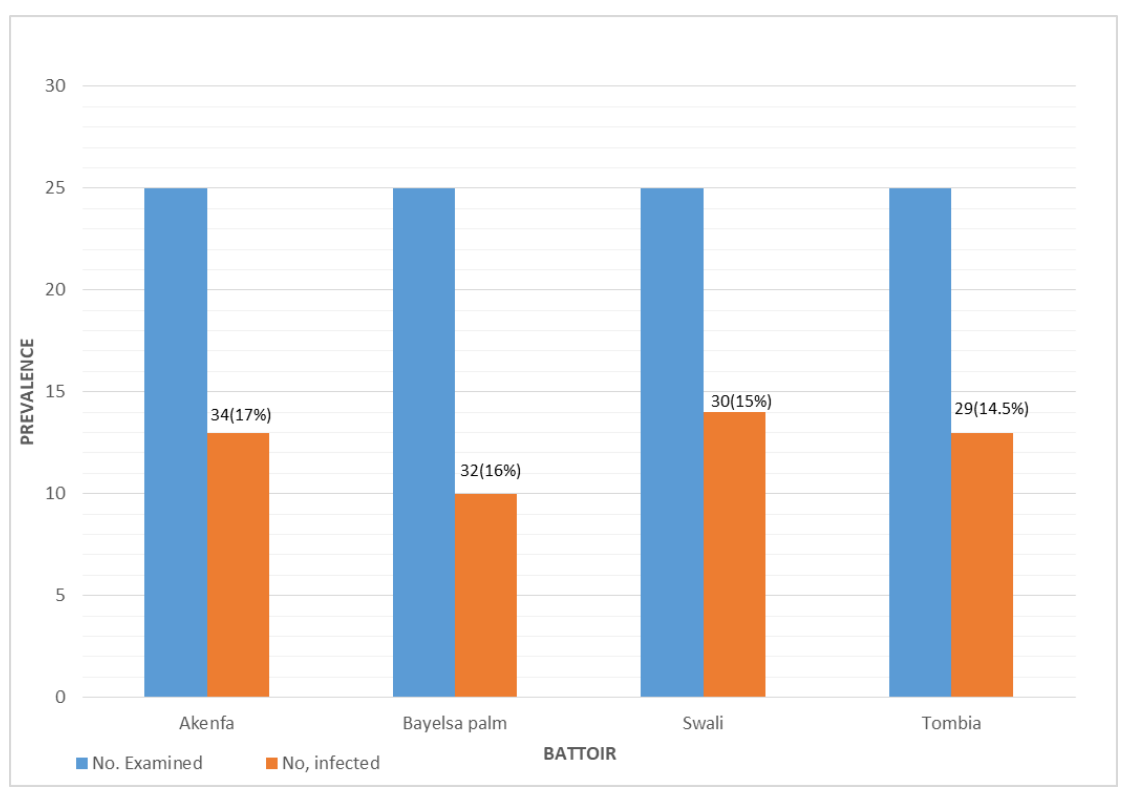

Figure 2 Prevalence of tick-borne haemoparasites in Zebu cattle (Bos taurus indicus) in Yenagoa metropolis

\subsection{Prevalence of tick-borne haemoparasites in relation to sex of cattle}

Out of the 125 infected cattle, 50(42\%) and 75(60\%) were males and females respectively

Table 1 Prevalence of tick-borne haemoparasites in relation to sex of Zebu cattle

\begin{tabular}{|l|c|c|c|c|c|}
\hline & \multicolumn{2}{|c|}{ MALE } & \multicolumn{2}{c|}{ FEMALE } & TOTAL \\
\hline Abattoir & No. Examined & No. Infected (\%) & No. Examined & No. Infected (\%) & \\
\hline Akenfa & 25 & $13(52)$ & 25 & $21(84)$ & \\
\hline Bayelsa palm & 25 & $10(40)$ & 25 & $22(88)$ & \\
\hline Swali & 25 & $14(56)$ & 25 & $16(64)$ & \\
\hline Tombia & 25 & $13(52)$ & 25 & $16(64)$ & \\
\hline Total & 100 & $50(50)$ & 100 & $75(75)$ & $125(62.5 \%)$ \\
\hline
\end{tabular}

\subsection{Prevalence of tick-borne haemoparasites in relation of species of parasites}

The results of the study indicated that 121 species of tick-borne haemoparasites belonging to to three genera where identified. The parasites were Anaplasma marginale 69(57.5\%), Babesia bovis 43(35.8\%) and Theileria parva 8(6.7\%) (Table 2). There was a statistical difference $(\mathrm{P}<0.05)$. Although there were numerical differences in the value obtained from difference abattoirs, this was not statistically significance $(\mathrm{P}>0.05)$.

Table 2 Prevalence of tick-borne haemoparasites in Relation of species of parasites

\begin{tabular}{|l|c|c|c|c|}
\hline Abattoir & \multicolumn{3}{|c|}{ Species of parasites } & Total \\
\hline & Anaplasma marginale & Babesia bovis & Theileria parva & \\
\hline Akenfa & $15(21.7)$ & $9(20.9)$ & $3(37.5)$ & $27(22.3)$ \\
\hline Bayelsa palm & $16(23.1)$ & $13(30.2)$ & $1(12.5)$ & $30(24.8)$ \\
\hline Swali & $20(29.0)$ & $10(23.2)$ & $4(50.0)$ & $34(28.0)$ \\
\hline Tombia & $18(26.0)$ & $11(25.6)$ & $1(12.5)$ & $30(24.1)$ \\
\hline Total & $69(57.5)$ & $43(35.8)$ & $8(6.7)$ & 121 \\
\hline P- Value & 0.051 & 0.350 & 0.181 & 0.158 \\
\hline
\end{tabular}




\subsection{Effects of tick-borne haemoparasites on some haematological parameters (PCV, HBG, WBC, RBC, MCV, MCH and MCHC}

The values for PCV, HBG, RBC and MCV in infected cattle were 25.53 $\pm 0.70,8.60 \pm 0.30,8.00 \pm 0.61$ and $24.00 \pm 0.99$ respectively (Table 3 ). These values were significantly lower than the standard value provided by WHO (2010).

Table 3 Effects of tick-borne haemoparasites on some haematological parameters (PCV, HBG, WBC, RBC, MCV, MCH and MCHC)

\begin{tabular}{|l|c|c|}
\hline Parameters & Conc. in infected cattle & Reference Range [18] \\
\hline PCV $(\%)$ & $20.53 \pm 0.70$ & $30-45$ \\
\hline HBG $(\mathrm{g} / \mathrm{dL})$ & $8.60 \pm 0.30$ & $10-25$ \\
\hline $\mathrm{WBC}\left(\times 10^{3} / \mu \mathrm{L}\right)$ & $10.21 \pm 0.30$ & $4-12$ \\
\hline $\mathrm{RBC}\left(\times 10^{6} / \mu \mathrm{L}\right)$ & $8.00 \pm 0.61$ & $9-15$ \\
\hline $\mathrm{MCV}(\mathrm{fL})$ & $24.00 \pm 0.99$ & $39-55$ \\
\hline $\mathrm{MCH}(\mathrm{pg})$ & $8.15 \pm 0.43$ & $13-17$ \\
\hline MCHC $(\mathrm{mg} / \mathrm{dL})$ & $31.91 \pm 0.92$ & $30-36$ \\
\hline
\end{tabular}

\section{Discussion}

Tick-borne haemoparasites is a serious health issue in livestock production globally especially in developing countries. The parasites cause various disease condition in cattle, ranging from anaemia, weight loss, jaundice to infertility thereby reducing the protein and economic value of the animals. The high prevalence $(62.5 \%)$ of tick-borne haemoparasites recorded in this study is higher than the $57.1 \%$ and $27.8 \%$ reported by [19] and [20] in Abeokuta, Ogun state and $16 \%$ recorded by [9] in North Central Nigeria. The result obtained in this study is also higher than the 13.5\% reported in Maiduguri by [21]. The result in this study is however lower than the 73.4\%, reported in Botswana by [22], 86.6\% in Mungwi District, Northern Province, Zambia by [23] and 80.4\% in North Cameroon by [24]. The differences in geographical location, sample sizes used, presence and spread of competent vector could account for these differences in results.

More females Zebu cattle (75\%) were infected than male cattle (50\%) in the study area. This is in agreement with the results of [9] who recorded high prevalence in females than in males. Although the prevalence rate differed in females (36.1\%) females and male (29.6\%) infection of cattle in North Central Nigeria. Similarly, [25] also recorded 4.44\% and $2.22 \%$ for males and females respectively in Ibadan metropolis, Oyo state, Nigeria. The results in this study is however contrary to the report of [20] who reported $51.2 \%$ males and $48.8 \%$ females were infected by haemoparasites at Abeokuta, Nigeria.

From all results obtained, it is clear that both females and males are susceptible to infection by tick-borne haemoparasites in areas where the disease vectors are endemic. This susceptibility could be attributed to the fact that both male and female cattle are exposed to the vector through the poor management practices. In this study, more females were infected than males and no clear reasons could be deduced for this observation since the same number of males and females were sampled for examination. However, calving and milk production as well as poor treatment could lead to compromised immunity in females could results in the build-up of parasites due to prolong contact with vectors [20]. Again, females are kept longer in the ranch for reproductive purposes, with only the old, weak and less productive ones sold to butchers for slaughter at the abattoirs. This practice could lead to build-up of parasites in the blood of infected animals.

The study reported the presence of three tick-borne haemoparasites (Anaplasma marginale., Babesia bovis and Theileria parva) in the Zebu cattle (Bos taurus indicus in the study area. This report is in line with the result obtained among cattle in Abeokuta [20] , Mungwi District, Northern Province, Zambia by [23], Ghana by [26] and in Western Kenya by [27]. [21] Also identified Anaplasma and Babesia in goats and sheep in abattoirs in Maiduguri.

The high prevalence of $57.5 \%$ and $35.8 \%$ recorded for Anaplasma marginale and Babesia bovis in this study respectively is higher than the $18.5 \% \%$ and $8.0 \%$ for these parasites reported by[20]. The result is also higher than the record by 
[21] for Anaplasma and Babesia. However, the prevalence rate of $6.7 \%$ observed for Theileria parva in this study is lower than the $9.3 \%$ recorded by [20].

The study further recorded a significance decrease $(\mathrm{P}<0.05)$ in the concentration of PCV, Hb, RBC and MCV in infected cattle compared to the normal range by [8]. This is similar to the report by [21,9]. This observation could be attributed to anaemia, a major feature that often serves as a dependable pointer for severe cases of haemoparasitic infections [26, 29]. Anaplasmosis and babesiosis are known causes of anaemia in haemaoparasite-infected animals [29].

This study recorded an increase in WBC counts in infected cattle. This is contrary to the significant reduction in total WBC counts of in goats and sheep recorded by [21] and in dromedary camels by [30]. The difference in results could be attributed to the differences in animals investigated, immune status of the animals and differences in study area.

\section{Conclusion}

The result of this study is an indication of the high prevalence of tick-borne haemoparasitic infections in the study area. This might be responsible for the anaemic condition and emaciation of cattle reared extensively in Nigeria. There is therefore serious need for routine medication examination and treatment of cattle in the study area.

\section{Compliance with ethical standards}

\section{Acknowledgments}

The authors appreciate the assistance the executives of National Union of Butchers, Bayelsa State and the abattoir workers as well as the laboratory workers in Wiz-Link research laboratory, Yenegoa.

\section{Disclosure of conflict of interest}

The authors declared that there is no conflict of interest.

\section{Statement of ethical approval}

The ethical approval for this work was granted by the Ministry of Agriculture, Bayelsa State. The National Union of Butchers, Bayelsa State also gave its written consent.

\section{References}

[1] Thornton PK. Livestock production: Recent trends, future prospects. Phil. Trans. R. Soc. B. 2010; 365: $2853-2867$.

[2] Adamu BS, Balarabe LM. Prevalence of haemoparasites of sheep and goats slaughtered in Bauchi Abattoir. Int J Appl Biol Res. 2012; 4: 128-133.

[3] Allred DR. Babesiosis: persistence in the face of adversity. Trends Parasitol. 2003; 19(2): 51-5.

[4] Blench R. Traditional Livestock Breeds: Geographical distribution and dynamic in relation to the ecology of West Africa. Working paper, Overseas Development Institute Portland House Stag Place London. 2002.

[5] Lawal-Adebowale AO. Dynamics of ruminant livestock management in the context of Nigeria Agricultural System and Technology. 2012.

[6] Sansoucy R. Livestock- a driving force for food security and sustainable development. World and Rev. 1995 ; 84 /85: 5-17.

[7] Zulfiqar S, Shahnawaz S, Ali M, Bhutta AM, Iqbal S, Hayat S, Qadir S, Latif M, Kiran N, Saeed A, Ali M, Iqbal F. Detection of Babesia bovis in blood samples and its effect on the hematological and serum biochemical profile in large ruminants from Southern Punjab. Asian Pac J Trop Biomed. 2012; 2(2): 104-108.

[8] World Health Organisation. Haematological Parameters. IT’S WHO Publications. 2010.

[9] Kamani J, Sannusi A, Egwu OK, Dogo GI, Tanko TJ, Kemza S. Prevalence and significance of haemoparasitic infections of cattle in North-Central, Nigeria. Vet World. 2010; 3(10): 445-448.

[10] Nwoha RIO, Onyeabor A, Igwe KC, Daniel G, Onuekwusi GCO, Okah U. Prevalence of haemoparasites in livestock in Ikwuano Local Government Area of Abia State. J Fisheries Livest Prod. 2013; 1: 3. 
[11] Bakre A, Omotosho 0, Adelakun 0, Alaba B. Prevalence of haemoparasites in Cattle slaughtered at Central Abattoir in Igboora, Oyo State, Nigeria. International Journal of Livestock Research. 2020; 10(10): 74-79.

[12] Onoja II, Mshelia WP, Okaiyeto SO, Danbirni S, Kwanashie G. Prevalence of babesoisis in cattle and goats at Zaria abattoir, Nigeria. J of Vet Adv. 2013; 3(7): 211-214.

[13] Nigera Population Commission. Nigeria demographic and health survey, NPC. 2006.

[14] Cheesbrough M. District laboratory practice in tropical countries. Cambridge University Press. London. 2005.

[15] Soulsby EJL. Helminths Arthropods and Protozoa of Domesticated Animals, (7th Edition), London. 2010.

[16] Brar RS, Sandhu HS, Singh A. Veterinary clinical diagnosis by laboratory methods (1 ${ }^{\text {st }}$ Ed). Kaylani Publishers 2000.

[17] Salih DA, Hussein AM, Singla LD. Diagnostic approaches for tick-borne haemoparasites diseases in livestock. J Vet Med Animal Health. 2015; 7(2): 45-56.

[18] Merck Manual. Haematologic reference ranges. Mareck Veterinary Manual. 2012.

[19] Okwelum N, Iposu SO, Ihasuyi PS, Sanwo K, Oduguwa BO, Amole TA, Shittu OO, Famakinde SA, Olugbogi EI, Takeet OVA, Oyewusi JA, Yusuff MA. Prevalence of trypanosoma infection in cattle in the teaching and research farm (TREFAD), University of Agriculture, Abeokuta, Ogun State, Nigeria G.J.B.A.H.S. 2013; 2(3): 161-164.

[20] Sam-Wobo SO, Uyigue J, Surakat OA, Adekunle NO, Mogaji HO. Babesiosis and other heamoparasitic disease in a Cattle slaughtering abattoir in Abeokuta, Nigeria. Int J Trop Dis Health. 2016; 18 (2): 1-15.

[21] Egbe-Nwiyi TN, Sherrif GA, Paul, BT. Prevalence of tick-borne haemoparasitic diseases (TBHDS) and haematological changes in sheep and goats in Maiduguri abattoir .J Vet med Animal Health. 2018; 10(1): 28-33.

[22] Raboloko OO, Ramabu SS, Guerrini L, Jori F. Seroprevalence of Selected Tick Borne Pathogens and Diversity and Abundance of Ixodid Ticks (Acari: Ixodidae) at the Wildlife-Livestock Interface in Northern Botswana. Frontiers Vet Sci. 2020; 7: 187.

[23] Tembo S, Collins NE, Sibeko-Matjila KP, Troskie M, Vorster I, Byaruhanga C, Oosthuizen, MC. Occurrence of tickborne haemoparasites in cattle in the Mungwi District, Northern Province, Zambia. Ticks Tick Borne Dis. 2018; 9(3): 707-717.

[24] Abanda B, Paguem A, Abdoulmoumini M. Kingsley MT, Renz A, Eisenbarth A. Molecular identification and prevalence of tick-borne pathogens in zebu and taurine cattle in North Cameroon. Paras Vect. 2019; 12: 448.

[25] Okoroafor UP, Nzeako SO. Prevalence of haemoparasites of cattle from three abattoirs in Ibadan Metropolis, Oyo state, Nigeria. Int J Sci Res Env Sci. 2014; 2(7): 244-249.

[26] Bell-Sakyi L, Koney EB, Dogbey 0, Walker AR. Incidence and prevalence of tick-borne haemoparasites in domestic ruminants in Ghana. Vet Parasitol. 2004; 124(1-2): 25-42.

[27] Njiiri NE, Bronsvoort BM, Collins NE, Steyn HC, Troskie M, Vorster I, Thumbi SM, Sibeko KP, Jennings A, van Wyk IC, Mbole-Kariuki M, Kiara H, Poole EJ, Hanotte O, Coetzer K, Oosthuizen MC, Woolhouse M, Toye P. The epidemiology of tick-borne haemoparasites as determined by the reverse line blot hybridization assay in an intensively studied cohort of calves in western Kenya. Vet Parasitol. 2015; 210(1-2): 69-76.

[28] Anosa VO. Haematological and biochemical changes in human and animal trypanosomosis. Part 1 Revue d'Elevage Medicine Veterinarie des pays Tropicaux. 2018; 11(41): 65-78.

[29] Rymaszewska A, Grenda S. Bacteria of the genus Anaplasma. Characteristics of Anaplasma and their vectors: A Review. Vet Med. 2009; 53(11): 573-584.

[30] Swelum AA, Ismael AB, Khalaf AF, Abouhelf MA, Tindall P. Clinical and laboratory findings associated with naturally occurring babesiosis in dromedary camels. Bull. Vet Inst Pulawy. 2014; 58(2): 229-233. 